\title{
Effects of organic amendment on some soil physicochemical characteristics and vegetative properties of Zea mays in wetland soils of the Niger Delta impacted with crude oil
}

\author{
Francis E. Egobueze ${ }^{1}$ Josiah M. Ayotamuno ${ }^{2}$ Chukwujindu M. A. Iwegbue ${ }^{3} \cdot$ Chibogwu Eze $^{1}$. \\ Reuben N. Okparanma
}

Received: 29 August 2018 / Accepted: 13 November 2019 / Published online: 3 December 2019

(c) The Author(s) 2019, corrected publication 2019

\begin{abstract}
Purpose This study sought to investigate the effects of organic amendments on the degradation of hydrocarbons and vegetative properties of Zea mays grown in crude oil-contaminated wetland soils of the Niger Delta, Nigeria.

Methods Two soil types were investigated, namely, fadama soil (oxisol) and swamp forest soil (utisol). For each soil type, 48 treatment cells and 1 control containing $1 \mathrm{~kg}$ of soil each were spiked with crude oil at concentrations ranging from 50 to $200 \mathrm{~g} \mathrm{~kg}^{-1}$, representing 5-20\% (m/m) contamination levels, respectively. Then, 5 days after the contamination, the soils were amended with cow dung (CD), poultry waste (PW), and palm oil waste (POW). The ratios of soil to organic amendments used were 1:1 and 2:1. The soils were tilled and irrigated regularly, and monitored for a total period of 112 days. The same conditions were used to investigate the vegetative properties of $Z$. mays in these oil-contaminated soils with organic amendments.

Results The total organic carbon (TOC) and $\mathrm{pH}$ increased significantly within the first 2 weeks after crude oil contamination; thereafter, the $\mathrm{pH}$ of the soil decreased significantly over incubation time, while there was steady increase in TOC with incubation time. The percentage nitrogen and total petroleum hydrocarbons (TPH) decreased significantly. The utisol soil showed better plant performance, despite the lower hydrocarbon degradation rate.

Conclusion The organic amendments showed a TPH degradation trend that followed the order: PW $>$ CD $>$ POW. They also improved the seed emergence of Zea mays.
\end{abstract}

Keywords Crude oil contamination $\cdot$ Organic amendment $\cdot$ Physicochemical properties $\cdot$ Wetland soil

\section{Introduction}

Soil contamination by petroleum hydrocarbons is a widespread global environmental issue because of the heavy reliance on petroleum as a foremost source of energy. The discharge of hydrocarbons into the environment by accident

Chukwujindu M. A. Iwegbue

maxipriestley@yahoo.com

1 Institute of Geoscience and Space Technology, Port Harcourt, Nigeria

2 Department of Agricultural and Environmental Engineering, Rivers States University of Science and Technology, Nkpolu-Oroworoko, Port Harcourt, Nigeria

3 Department of Chemistry, Delta State University, P.M.B. 1, Abraka, Delta State, Nigeria or through anthropogenic activities is a major source of environmental pollution (Holliger et al. 1997). These hydrocarbon pollutants usually distort the natural equilibrium between living species and their natural environment. Contamination by hydrocarbons in the environment is a cause of concern, because a number of these hydrocarbons are known to be carcinogenic, mutagenic, neurotoxic and can disrupt immune and endocrine systems (Das and Chandran 2011; Iwegbue et al. 2017, 2019).

The Niger Delta of Nigeria is a densely populated petroleum-rich area. This fragile ecosystem has been severely impacted by the effects of oil. The degradation of Niger Delta soils is related to oil spills in the region, of which there have been many thousands of incidents. The soil flora and fauna in this area are under serious threat because of the deleterious effects of crude oil. Oil spills occur mainly as a result of equipment failure, corrosion and vandalization. 
Crude oil spills adversely affect soil function and service by alteration of the natural equilibrium that exists between the physical, chemical and biological characteristics of the soil. These alterations have serious consequences on soil fertility, plant communities and entire ecosystems (Etuk et al. 2013). The effects of crude oil on soil properties and plants are influenced by its concentration in the soil. Crude oil pollution can negatively affect the soil $\mathrm{pH}$ structure, bulk density, porosity, aeration, and nutrient availability and uptake by plants (Ekundayo et al. 2001; Uquetan et al. 2017). Crude oil contamination increases the organic matter content and electrical conductivity of soil but decreases the available nitrogen, phosphorus and exchangeable acidity. A number of studies have shown that concentrations above $3 \%$ of crude oil in soil can cause adverse changes in soil properties and plant growth (Ekundayo et al. 1989; Chukwu and Udoh 2014). Crude oil in soil can adversely affect germination, plant height and biomass content of the plant (Ogboghodo et al. 2004).

Soils impacted with crude oil require restoration to their natural state so that they can support plant growth and other ecosystem services. The use of microorganisms, such as bacteria and fungi, in the degradation of petroleum hydrocarbons in the environment has been established (Ogbonna et al. 2012). A number of soil amendment methods have been applied as bioremediation strategies to facilitate ecosystem restoration processes. One promising method is the use of chemical fertilizers to boost the soil nutrients, especially nitrogen and phosphorus, to improve the microbial population during biodegradation of crude oil in contaminated soil (Ayotamuno et al. 2006). This method shares the advantages of being economical, efficient, versatile and environmentally friendly (Margesin and Schinner 2001; Yakubu 2007), but cannot improve the soil structure, textural characteristics, water holding capacity and organic matter content. Hence, amendment of crude oil-contaminated sites with organic waste is an efficient, cost-effective method of soil restoration since alongside improving the soil structure and other soil physicochemical properties, it also solves solid waste management problems.

From the aforementioned, it is clear that it is imperative to undertake amendment studies of oil-contaminated sites to determine which organic wastes can restore soil function and degrade the hydrocarbons present. It is also important to determine the crop-bearing ability of these amended soils. With this in mind, the objectives of this study were to determine (1) the effects of organic amendments, namely, cow dung, and poultry and palm oil wastes, on the degradation of petroleum hydrocarbons in selected soil types of the Niger Delta contaminated with crude oil, and (2) the effects of the organic amendments on the vegetative properties of Zea mays grown in crude oil-contaminated soil. The information obtained from this study will be useful for developing effective soil restoration strategies and for the management of crude oil-contaminated sites.

\section{Materials and methods}

\section{Sample collection}

Three hundred kilograms each of two different prominent soil types: oxisols (fadama) and utisols (swamp forest soils), with no recorded incidents of previous crude oil contamination in the Niger Delta were collected from a depth of $0-20 \mathrm{~cm}$. The freshwater forest swamp soil was collected in the Emu-Uno area of Ndokwa West Local Government Area of Delta State with coordinates of N $04^{\circ} 38^{\prime} 14.5^{\prime \prime} \mathrm{E} 06^{\circ} 12^{\prime} 10.20^{\prime \prime}$ and the fadama soil was collected at Aghalokpe in Okpe Local Government Area of Delta State with coordinates N $04^{\circ} 59^{\prime} 41.05^{\prime \prime}$ E $06^{\circ}$ $06^{\prime} 09.05^{\prime \prime}$ (Fig. 1). The three different types of organic amendments, namely, cow dung was collected from the abattoir at Agbor, and poultry waste and palm oil waste were collected from a poultry farm and a palm oil processing mill in Obiaruku.

\section{Soil treatment and bioremediation setup}

The fadama and forest swamp soils were first sieved through a $2 \mathrm{~mm}$ mesh and then were air dried and pulverized. The experimental design was a complete randomized block with 48 treatment cells ( 2 soil types $\times 4$ oil-contamination levels $\times 2$ soil: organic waste amendment ratios $\times 3$ amendments) (Iwegbue et al. 2006, 2011, 2017), with 1 replicate of each and 2 controls, i.e. a total of 98 treatment cells. The experiment was carried out for a total period of 16 weeks (112 days). The soils were contaminated with Bonny light crude oil which was obtained from Total E\&P Nigeria Ltd. Different concentrations of the crude oil were added to the soil samples to represent minor, medium and major spill scenarios. The contamination ratios were 50, 100,150 and $200 \mathrm{~g} \mathrm{~kg}^{-1}$ representing 5, 10, 15 and $20 \%$ contamination loads, respectively. Once the oil was added to the soil, the samples were thoroughly mixed, and left untouched for $48 \mathrm{~h}$ to reduce the amount of toxic components in the oil through volatilization. The contaminated soils $(1 \mathrm{~kg})$ were placed in perforated plastic bags and amended 5 days after the contamination with each of cow dung $(\mathrm{CD})$, poultry waste (PW) and palm oil waste (POW) in a ratio of 1:1 and 2:1 (soil: organic materials). Each pot was properly mixed to ensure homogeneity and samples were taken for analysis at day $0,7,14,21,28,42,56$, 84 and 112. The moisture content of the organic wasteamended crude oil-contaminated soil was maintained at 
Fig. 1 Map indicating the two soil collection points

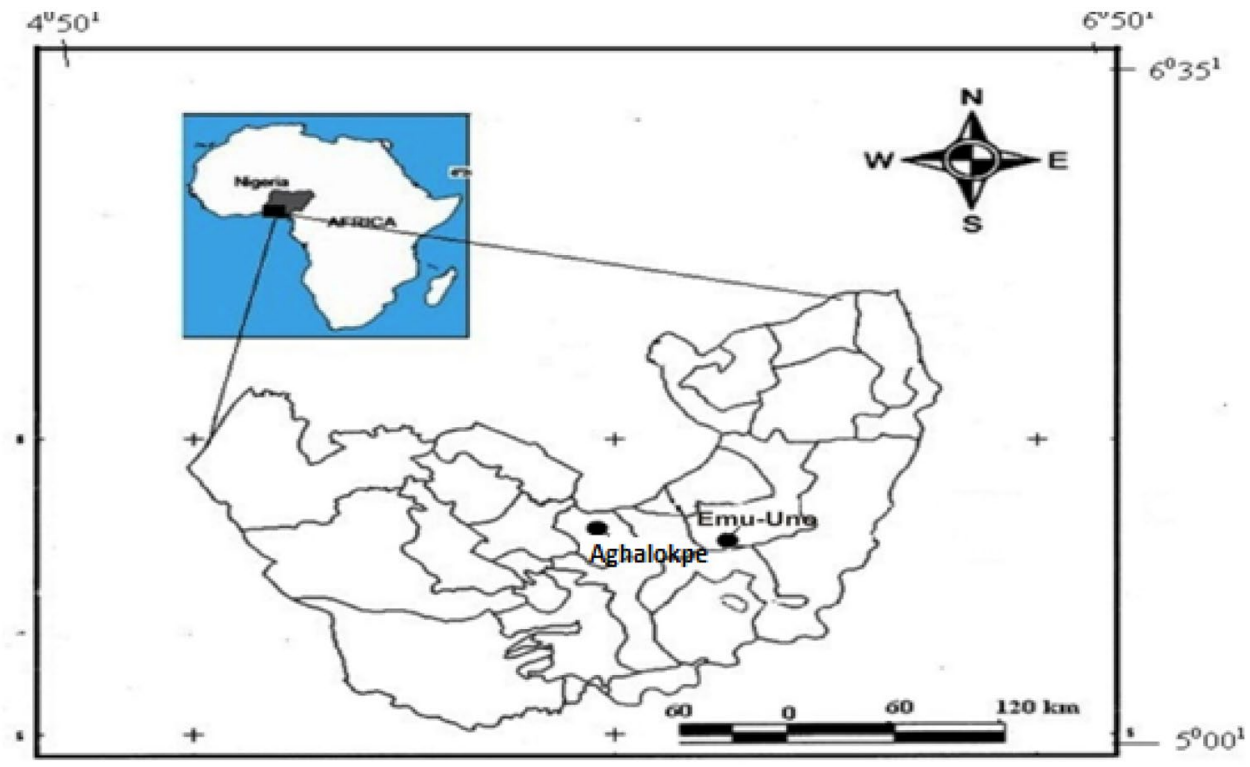

$60 \%$ water-holding capacity and the samples were incubated at room temperature $\left(28 \pm 2{ }^{\circ} \mathrm{C}\right)$. The treatment cells that contained only crude oil-contaminated soil at $5 \%$, $10 \%, 15 \%$ and $20 \%$ were used as a control. The organic waste-amended crude oil-contaminated soils were tilled twice a week to allow proper aeration and the moisture content was maintained at $60 \%$ water-holding capacity by irrigating with sterile distilled water.

\section{Chemical analysis of soil and organic wastes}

The two soil types and the three organic wastes used as soil amended materials were analysed for total nitrogen by the Kjeldahl method, while the Walkey and Black method was used for the determination of their total organic carbon content. The $\mathrm{pH}$ of the soils and organic amendment materials was measured in a 1:2.5 (m/v) soil: distilled water suspension after 30 min of equilibration with a $\mathrm{pH}$ meter (HANNA HI 8424). All analyses were carried out in triplicate with a precision of 5-9\% relative standard deviation. The total petroleum hydrocarbon (TPH) content of the soil samples was determined by the method of the Intergovernmental Oceanographic Commission (IOC) as described by Onianwa and Essien (1999). A mass of $100 \mathrm{~g}$ of each of the soil samples was refluxed with $100 \mathrm{ml}$ of methanol containing $3.0 \mathrm{~g}$ of $\mathrm{KOH}$ for $2.5 \mathrm{~h}$. The refluxed mixture was filtered; the filtrate was then extracted with two $25 \mathrm{ml}$ portions of high purity hexane and evaporated to approximately $1.0 \mathrm{ml}$. The extract was subjected to purification by solid phase extraction on a silica gel column using n-hexane as the eluting solvent. The eluate was subsequently evaporated to dryness under a gentle stream of pure nitrogen gas, and the residue was subsequently weighed. A recovery test procedure was carried out by spiking five previously analysed soil samples with various amounts of hydrocarbon oil and then following all the analysis steps. The average spike recoveries ranged between 85 and $94.8 \%$.

\section{Determination of the effects of organic amendments on the vegetative properties of Zea mays grown on crude oil-contaminated fadama and swamp forest soils}

The pot experiment was set up under greenhouse conditions and a total of 200 plastic containers measuring $30 \times 30 \mathrm{~cm}$ were used for the study. The plastic containers were perforated at the sides and bottom. Each of the containers was loaded with $1 \mathrm{~kg}$ of soil that had a crude oil contamination ratio of $50 \mathrm{~g} \mathrm{~kg}^{-1}, 100 \mathrm{~g} \mathrm{~kg}^{-1}, 150 \mathrm{~g} \mathrm{~kg}^{-1}$ and $200 \mathrm{~g} \mathrm{~kg}^{-1}$ (crude oil/soil) to give 5, 10, 15 and $20 \%$ contamination loads, respectively. The soils were thoroughly mixed with crude oil and allowed to stand for $48 \mathrm{~h}$. After 5 days, the crude oil-contaminated soils were amended with the organic waste materials, namely, cow dung, poultry waste and palm oil waste, in ratios of $1: 1$ and $2: 1$ (soil: organic material). The moisture content of the organic waste-amended-contaminated soils was maintained at $60 \%$ water-hold capacity and the samples were incubated at room temperature. The organic waste-amended-contaminated soils were watered constantly and allowed to stand for 7 days before planting. Five viable maize seeds were planted in each pot and thinned to three seedlings per pot 2 weeks after planting. The set-up was irrigated regularly throughout the period of the experiment. The experiment was organized in a completely randomized design with four treatments; each replicated 
three times (Ekundayo et al. 2001). The parameters studied include seed emergence, survival rate, number of leaves and plant height. Seed emergence was measured as the percentage of the ratio of the seedlings at 7 days after planting to the actual number of seeds planted per pot, the survival rate and number of leaves ( 5 weeks after planting) was determined by counting. Plant heights were measured weekly with a meter measuring tape for 5 weeks after planting (Ogboghodo et al. 2004).

\section{Results and discussion}

\section{Physicochemical properties of soils and organic wastes}

The $\mathrm{pH}$, organic carbon content, total nitrogen and other physicochemical characteristics of the two soil types used for the experiment varied significantly and corresponded to typical soil series of the Niger Delta as can be seen in Table 1.

The $\mathrm{pH}$ of the two soil types was 7.16 for the oxisols (fadama soil) and 6.31 for the utisols (swamp forest soil). These $\mathrm{pH}$ values were in the acid to near-neutral range, which is a typical characteristic of soils of the Niger Delta (Iwegbue et al. 2012; Iwegbue 2014). The percentages of total nitrogen $(\mathrm{TN})$ in the soils were generally low, while the TOC contents of the soils were close to the range for Niger Delta soils (Tanee and Albert 2011). The swamp forest soil had a higher TOC content than the fadama soil (Table 1).

The $\mathrm{pH}$ of the three organic wastes was in the alkaline range except for the palm oil waste (POW) (Table 1). Although the $\mathrm{pH}$ values of the organic amendment materials used in this study were higher than the reported values for goat droppings and poultry waste (Onuoha et al. 2014) the $\mathrm{pH}$ of the wastes used can promote the growth of bacteria, which thrive in near-neutral to alkaline soil (Onuoha et al. 2014). The total nitrogen content of the organic wastes used for the organic amendment ranged from 1.40 to $2.24 \%$ (Table 1).

\section{Effects of organic amendments on the pH of crude oil-contaminated fadama and swamp forest soils}

The effects of various treatment conditions, for example, fadama soil + cow dung, swamp forest soil + cow dung, and control (without cow dung), on the $\mathrm{pH}$ of the contaminated soils was monitored for a period of 42 days. In general, for the cow dung amendment, the fadama soil showed a slight increase in soil acidity but did not exceed a $\mathrm{pH}$ value of 7 (Fig. 2a), while the swamp forest soil showed a decrease in $\mathrm{pH}$ with respect to time (Fig. 2b).

The swamp forest and fadama soils treated with poultry waste showed a slight increase in $\mathrm{pH}$ over time, while both soils showed a slight decrease in $\mathrm{pH}$ over time when amended with palm oil waste. Overall, the treatment with cow dung induced higher mean $\mathrm{pH}$ values with swamp forest soil than with fadama soil and the control. However, treatment with poultry and palm oil wastes exhibited higher mean $\mathrm{pH}$ values with fadama soil than with swamp forest soil and the control. The initial increase in $\mathrm{pH}$ observed in this study after soil contamination agrees with previously reported findings that the acidity of the soil increases with increased crude oil pollution (Osuji and Adesiyan 2005; Obasi et al. 2013). The $\mathrm{pH}$ of the soil has a significant influence on soil flora and fauna, as well as the availability of soil nutrients necessary for plant growth and maintenance of plant metabolism. The increase in the $\mathrm{pH}$ of crude oil-polluted fadama soil amended with poultry waste also agrees with the report

Table 1 Physicochemical characteristics of the soil samples and organic amendments

\begin{tabular}{|c|c|c|c|c|c|}
\hline Parameters & Fadama (FAD) soil & $\begin{array}{l}\text { Swamp forest } \\
\text { (FOR) soil }\end{array}$ & Cow dung (CD) & $\begin{array}{l}\text { Poultry waste } \\
\text { (PW) }\end{array}$ & $\begin{array}{l}\text { Palm Oil } \\
\text { waste } \\
\text { (POW) }\end{array}$ \\
\hline $\mathrm{pH}$ & 7.16 & 6.31 & 12.59 & 9.54 & 6.97 \\
\hline Total nitrogen $(\mathrm{TN}, \%)$ & 0.06 & 0.13 & 1.70 & 2.24 & 1.40 \\
\hline Total organic carbon (TOC, \%) & 1.73 & 5.24 & 49.17 & 45.23 & 39.30 \\
\hline Carbon-nitrogen ratio $(\mathrm{C} / \mathrm{N})$ & 28.83 & 40.31 & 28.92 & 20.19 & 28.07 \\
\hline Sand $(\%)$ & 87.47 & 49.85 & N/A & N/A & N/A \\
\hline Clay (\%) & 9.23 & 38.15 & N/A & N/A & N/A \\
\hline Silt $(\%)$ & 3.30 & 12.00 & N/A & N/A & N/A \\
\hline USDA soil textural classification & Loamy-sand & Sandy-clay & N/A & N/A & N/A \\
\hline USDA soil order & Oxisols & Ultisols & N/A & N/A & N/A \\
\hline
\end{tabular}

Fadama is a Hausa term. It is a form of farming that explores planting of irrigated crops along riverbeds. In Nigeria, fadama soils are those located in fadama designated areas along the floodplains of the rivers Niger, Benue, Sokoto Rima, and Yobe

N/A Not applicable, USDA United States Department of Agriculture 
A
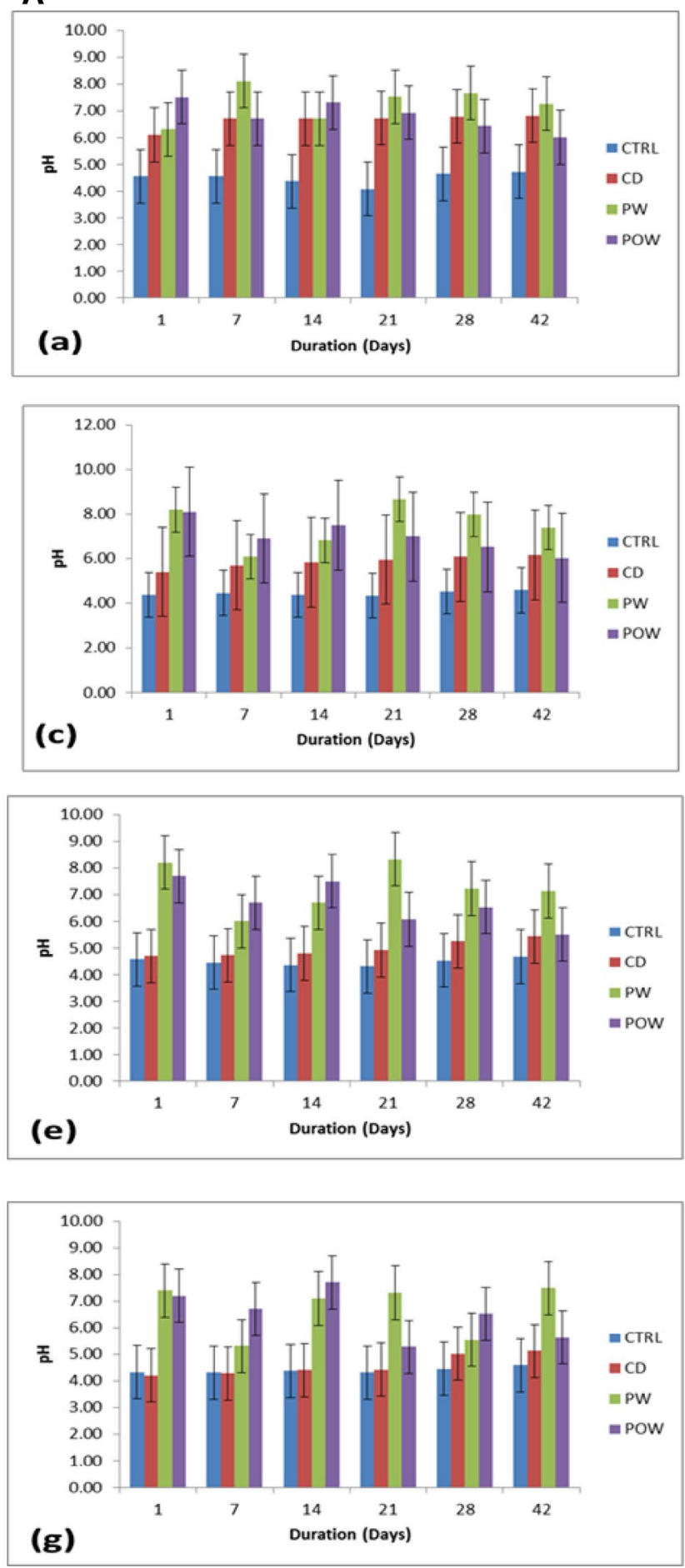

Fig. 2 a Effects of cow dung (CD), poultry waste (PW) and palm oil waste (POW) on $\mathrm{pH}$ of treated $\mathbf{A}$ fadama soil, $\mathbf{B}$ forest swamp soil. a 1:1 and $\mathbf{b} 2: 1$ soil to organic amendment ratio at $5 \%$ oil contamination, c 1:1 and d 2:1 soil to organic amendment ratio at $10 \%$ oil con-
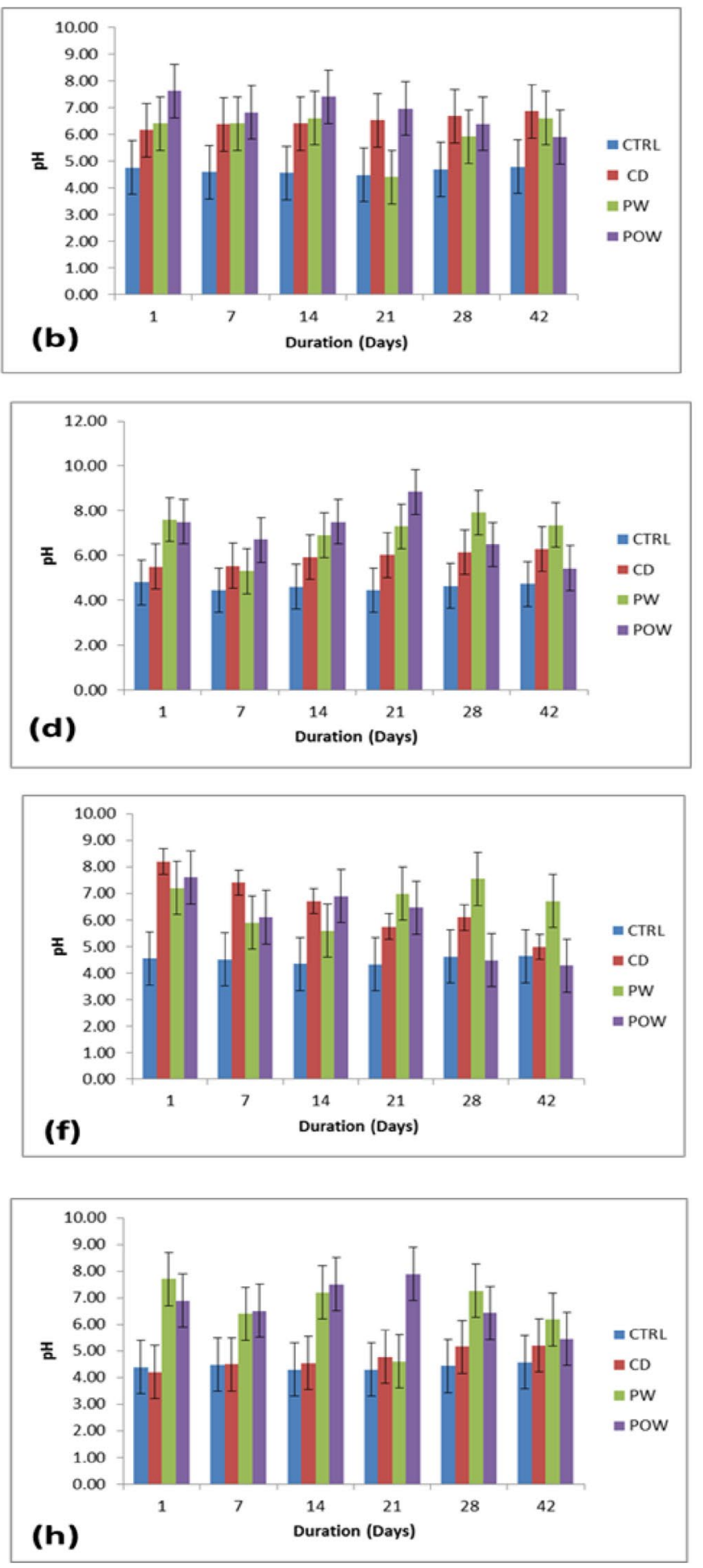

tamination, e 1:1 and $\mathbf{f} 2: 1$ soil to organic amendment ratio at $15 \%$ oil contamination, and $\mathbf{g} 1: 1$ and $\mathbf{h} 2: 1$ soil to organic amendment ratio at $20 \%$ oil contamination 
B
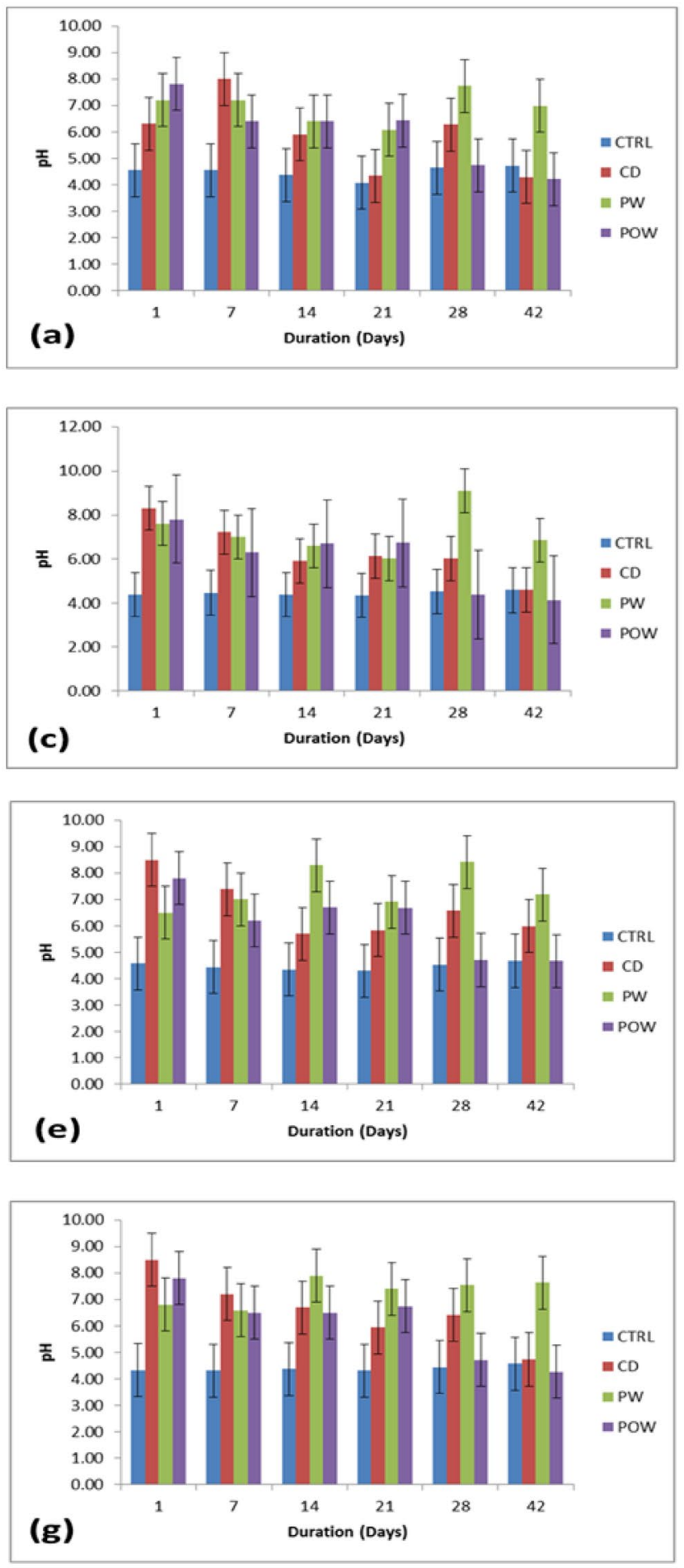

Fig. 2 (continued)

of Onuh et al. (2008). The observed increase in $\mathrm{pH}$ in soils amended with poultry waste, although only small and within the neutral-to-slightly alkaline range, is favourable since this
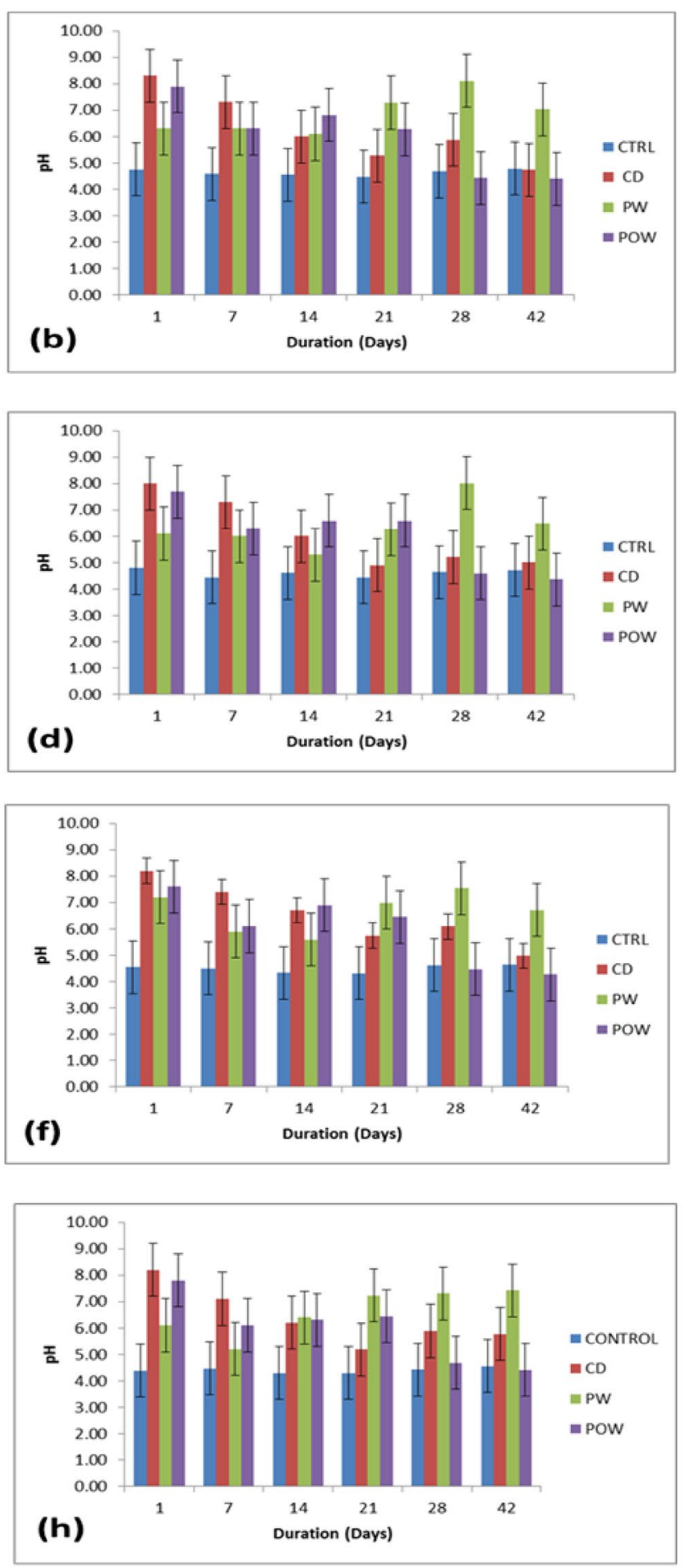

$\mathrm{pH}$ range is known to favour rapid carbon mineralization and organic matter breakdown (Obasi et al. 2013). 


\section{Effects of organic amendments on TOC content and nitrogen mineralization of crude oil-contaminated fadama and swamp forest soils}

The swamp forest and fadama soils amended with cow dung showed a higher increase in TOC content than the same soil treated with palm oil and poultry waste. The increase in the percentage of TOC over incubation time may have resulted from microbial mineralization of the crude oil. The results of the present study are in agreement with the reports of Amadi and Ue Bari (1992), Onuh et al. (2008), and Obasi et al. (2013), who observed an increase in the TOC content of crude oil-contaminated soil amended with saw dust, cow dung and poultry manure. The organic matter content of soil influences other properties such as water-holding capacity, bulk density and mobilization of nutrients (Obasi et al. 2013).

The addition of organic amendments resulted in a significant increase in nitrogen mineralization. The rate of nitrogen mineralization was higher in contaminated fadama soil with various treatment combinations than for swamp forest soil. This may be due to the high proportion of sand in the fadama soil (see Table 1). It has been reported that nitrogen mineralization is far more intense in sandy soil than clay soil when soils are amended with municipal waste sludge compost (Madrid et al. 2001). This is attributed to the fact that a greater amount of organic matter-clay complexes makes microbial attack in soil with high clay contents more difficult (Hérbert et al. 1991). However, contaminated fadama soil amended with PW showed a significantly higher rate of nitrogen mineralization than the same fadama soil amended with CD or POW. The mineralization rate decreased significantly with decrease in the quantity of amendment added (i.e. from 1:1 to 2:1 soil:organic amendments). Swamp forest soil with various treatment combinations showed lower mineralization rates than fadama soil with the same treatment combinations. The rate of mineralization of nitrogen is higher in PW- than CD- and POW-amended soils, because of the $\mathrm{C} / \mathrm{N}$ ratio of the waste used for incubation.

The addition of nutrient supplements to crude oil-contaminated soil was aimed to boost the nutrient elements needed for microbial degradation of petroleum hydrocarbons. Figures 3, 4 show the variation over time of TPH in the crude oil-polluted soils amended with organic wastes (i.e. cow dung, poultry waste and palm oil waste). The results showed a significant difference $(p<0.05)$ in the reduction of TPH in the soils amended with organic wastes as compared with the control without organic amendments. Soils amended with organic wastes recorded the highest levels of TPH reduction compared with the unamended contaminated soil (i.e. the control). A similar observation was reported for crude oil degradation in soil using poultry manure as an amendment material (Ijah and Antai 2003; Okolo et al. 2005), piggery manure (Yakubu 2007), and N-P-K fertilizer (Ayotamuno et al. 2006). Figures 3,4 further show that within the different contamination levels of 5, 10, 15 and 20\%, TPH reduction decreased with the increasing crude oil-contamination level. Fadama soil at a 5\% crude oil contamination level and a 1:1 amendment ratio treated with either cow dung, poultry waste or palm oil waste showed a TPH degradation of 82.10, 89.40 and $82.02 \%$, respectively, while swamp forest soil with the same treatments showed a TPH degradation of 79.87, 82.32 and $79.86 \%$, respectively. At a $20 \%$ contamination level with the same treatments (cow dung, poultry waste and palm oil waste) in fadama soil, the degradation was 67.00 , 68.34 and $60.78 \%$, while the similarly treated swamp forest soil exhibited TPH degradations of 55.63, 63.28 and 59.54\%, respectively. The trend of biodegradation in the different soil treatments followed the trend $\mathrm{PW}>\mathrm{CD}>\mathrm{POW}$. This trend follows the same order as the total $\mathrm{N}(\mathrm{TN})$ content of the wastes (see Table 1).

Hydrocarbon-utilizing bacteria require important nutrients, such as nitrogen and phosphorus, for effective and efficient degradation of hydrocarbons in the soil environment. Similar results were reported by Adesodun and Mbagwu (2008) in the study of the effect of some organic wastes on oil-polluted soil. This study has, therefore, demonstrated that crude oil biodegradation in wetland soils is also dependent on the soil classification. Soils with a larger sand fraction like fadama soil, which is an oxisol, have been shown to have faster total petroleum hydrocarbon biodegradation than forest swamp soil (utisol). This may be due to the ability of the oxisol to provide adequate aeration required for floral diversity and microbial support.

\section{Effects of organic amendments on the vegetative properties of Zea mays grown on crude oil-contaminated fadama and swamp forest soils}

The study further showed that application of $5 \%$ crude oil delayed the emergence of $Z$. mays by $2-4$ days and significantly reduced the percentage emergence in the contaminated soils amended with the different organic wastes. The results showing the number of leaves are presented in Fig. 6. In fadama soil, the numbers of leaves were highest at the $0 \%$ contamination over the 5 -week study period. The lowest number of leaves was recorded for the $20 \%$ contamination. Also, the results obtained in swamp forest soil followed the same trend as that of fadama soil, the lowest and highest number of leaves being recorded at 20 and $0 \%$, respectively.

The percentage of seed emergence was lowest in soils amended with oil palm wastes across the different contamination levels and organic amendment loadings. However, between the two soil types treated with the organic 

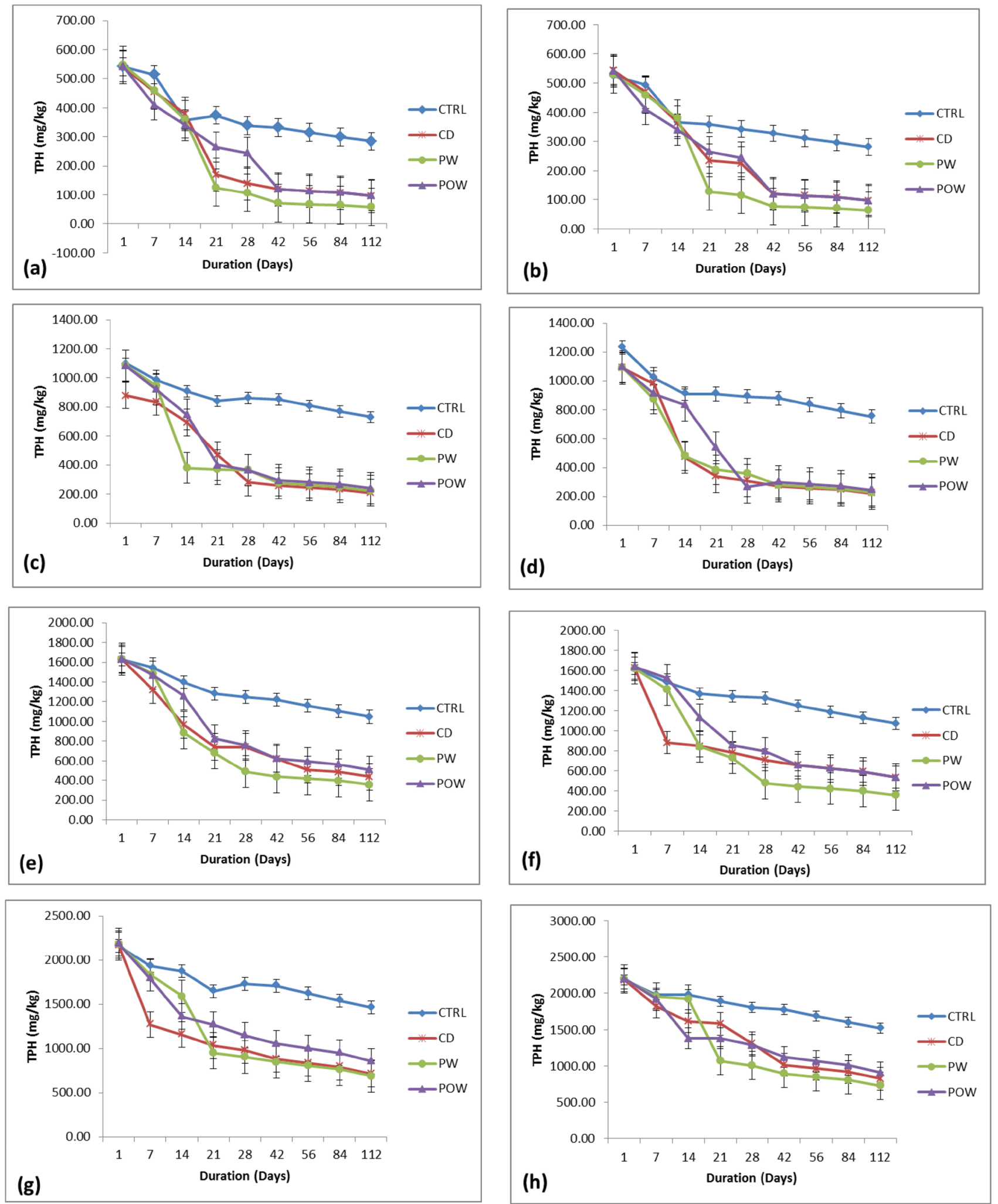

Fig. 3 Effects of cow dung (CD), poultry waste (PW) and palm oil waste (POW) on TPH of treated fadama soil. a 1:1 and $\mathbf{b} 2: 1$ soil to organic amendment ratio at 5\% oil contamination, $\mathbf{c} 1: 1$ and $\mathbf{d} 2: 1$ soil

to organic amendment ratio at $10 \%$ oil contamination, e 1:1 and $\mathbf{f} 2: 1$ soil to organic amendment ratio at $15 \%$ oil contamination, and $\mathbf{g} 1: 1$ and $\mathbf{h} 2: 1$ soil to organic amendment ratio at $20 \%$ oil contamination 

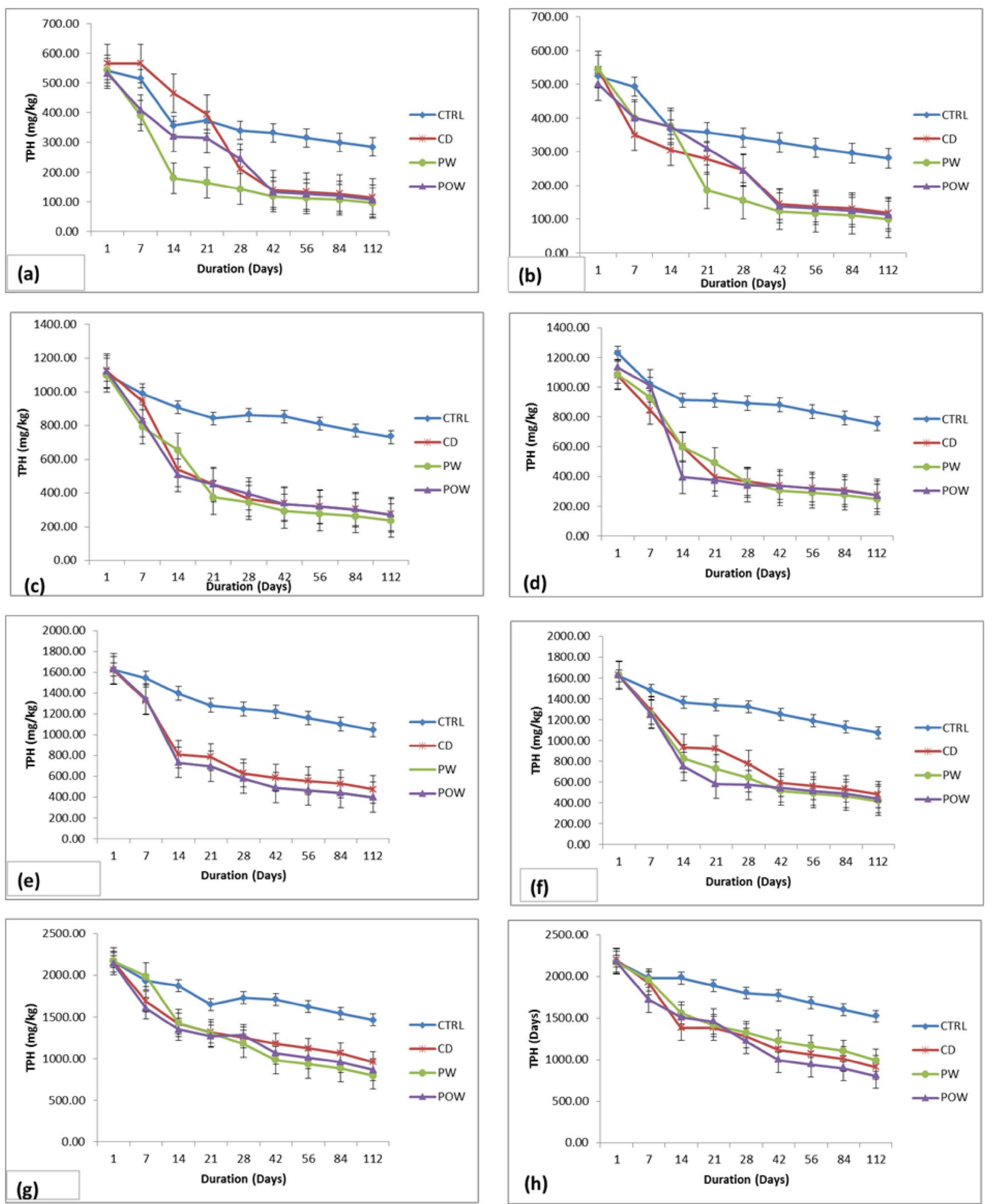

Fig. 4 Effects of cow dung (CD), poultry waste (PW) and palm oil waste (POW) on TPH of treated forest swamp soil. a 1:1 and b 2:1 soil to organic amendment ratio at $5 \%$ oil contamination, $\mathbf{c} 1: 1$ and $\mathbf{d}$ $2: 1$ soil to organic amendment ratio at $10 \%$ oil contamination, e 1:1

and $\mathbf{f} 2: 1$ soil to organic amendment ratio at $15 \%$ oil contamination, and $\mathbf{g}$ 1:1 and $\mathbf{h} 2: 1$ soil to organic amendment ratio at $20 \%$ oil contamination 
Fig. 5 Effect of loading rate of cow dung $(\mathrm{CD})$, poultry waste $(\mathrm{PW})$, and palm oil waste (POW) on seed emergence 5 weeks after planting for $\mathbf{a}$ fadama soil and $\mathbf{b}$ swamp forest soil
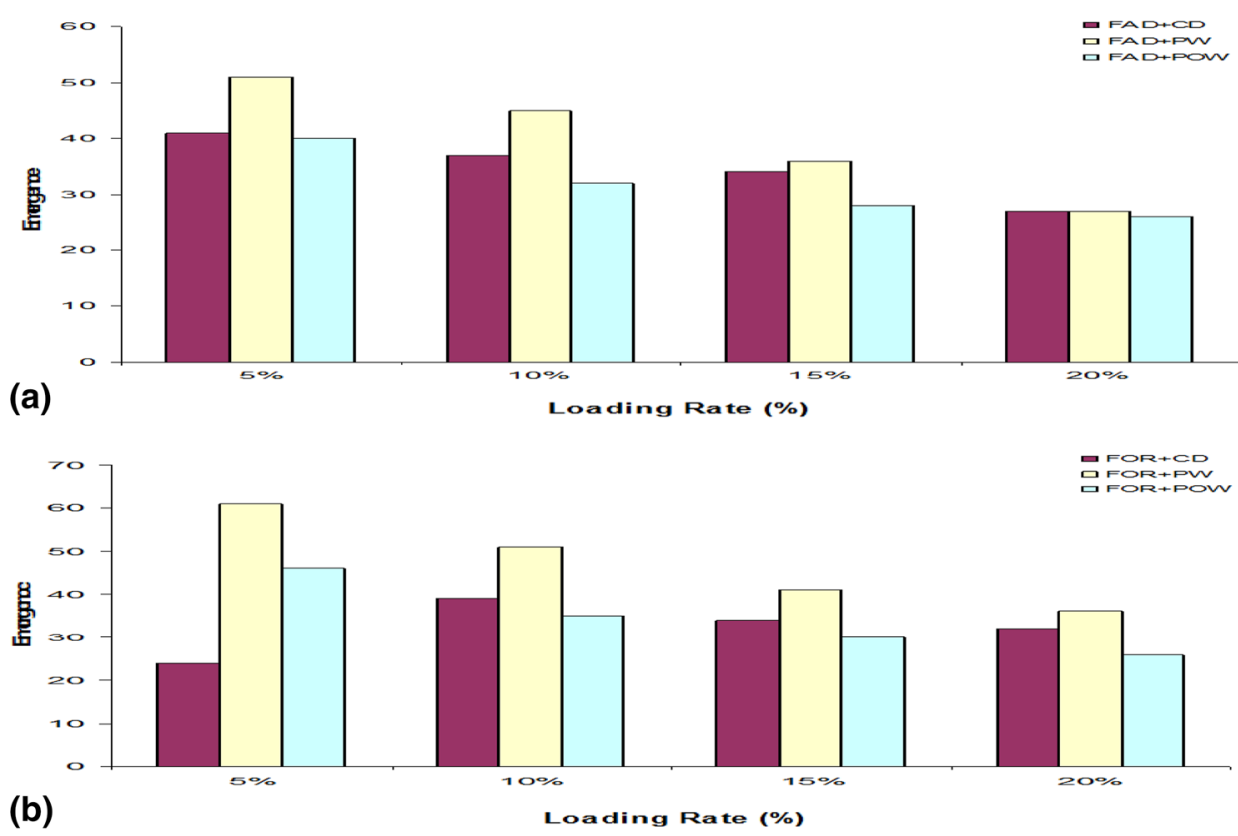

(b)

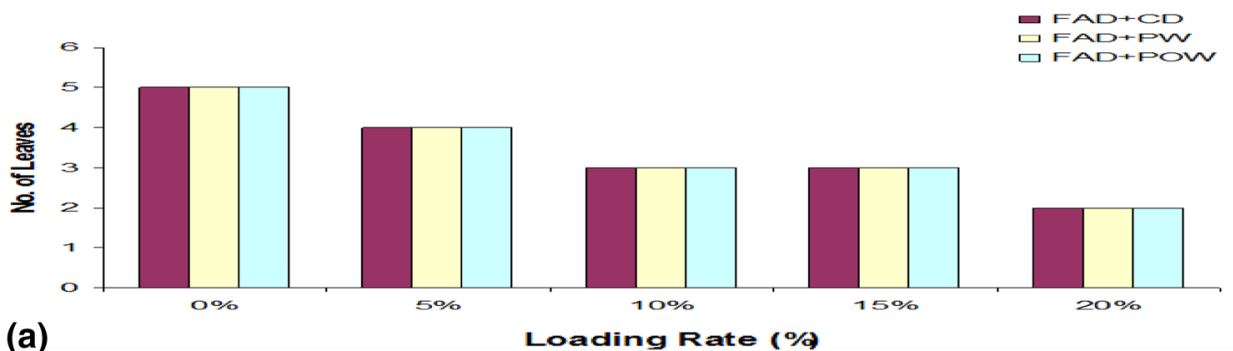

(a)

DFOR+CO

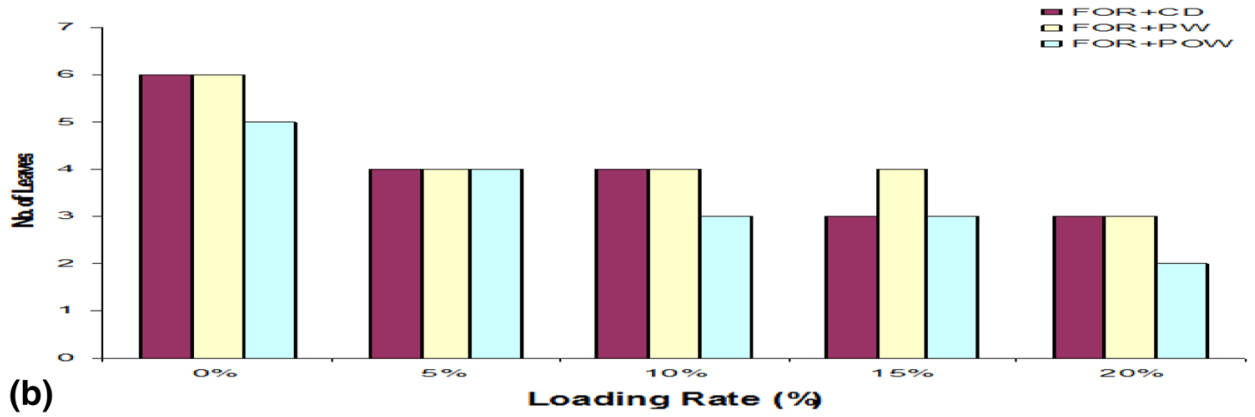

amendments at the same amendment loadings, swamp forest soil showed a better percentage of seed emergence than fadama soil. For example, the percentage seed emergence for a 1:1 soil to organic amendment (poulty waste) ratio was $48 \%$ and for a $2: 1$ ratio, it was $49 \%$ at a $5 \%$ oil contamination level of the swamp forest soil (Figs. 5, 6). The differences in the percentage of seed emergence may be attributed to differences in soil physicochemical characteristics that support the growth of $Z$. mays.
The effect of the organic amendments on plant height over time (Figs. 7, 8) showed that plant height increased with time.

However, for all treatment combinations, the plant heights recorded were less than those of the control. This may be due to the presence of the undegraded fraction of crude oil in the soils. The highest plant height was observed at a 5\% contamination level and an amendment ratio of 1:1 in swamp forest soil amended with cow dung and palm oil waste. Moreover, there were slight differences in plant height with respect to amendment ratio. 


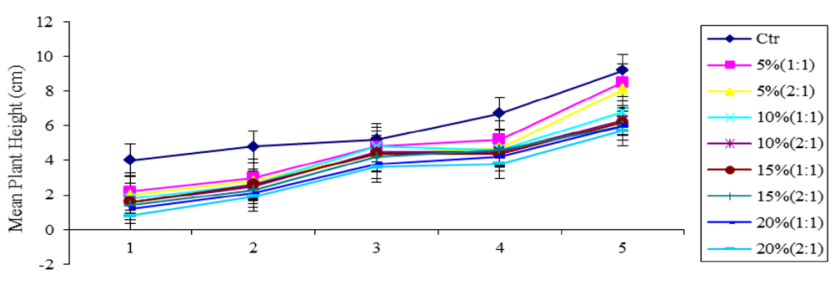

(a)

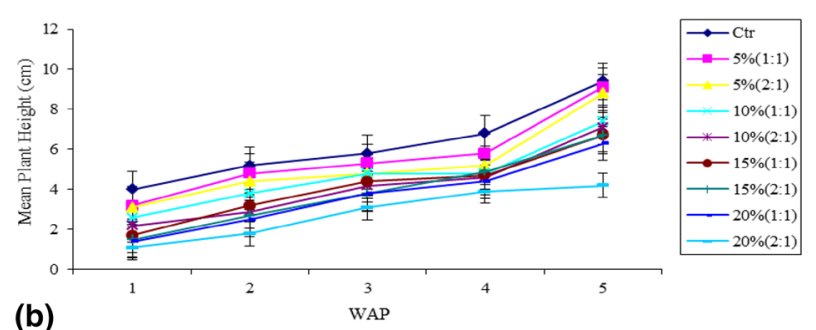

(b)

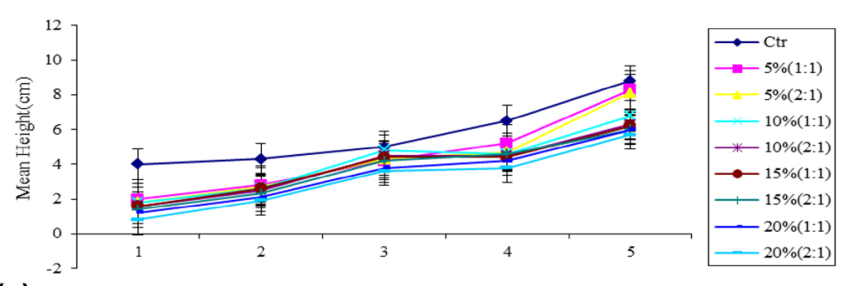

(c)

WAP

Fig. 7 Mean plant height as a function of weeks after planting (WAP) in oil-contaminated famada soil amended with a cow dung, b poultry waste and $\mathbf{c}$ palm oil waste

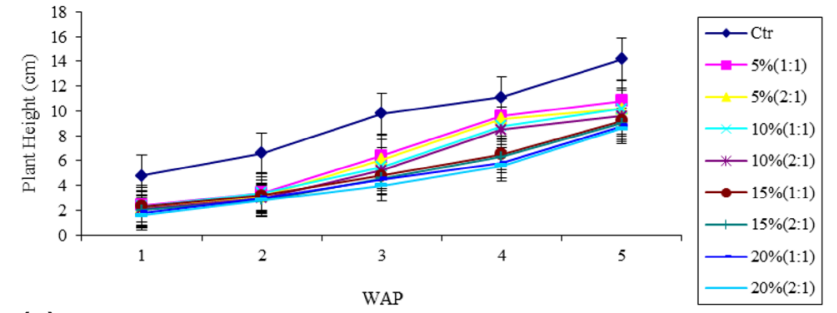

(a)

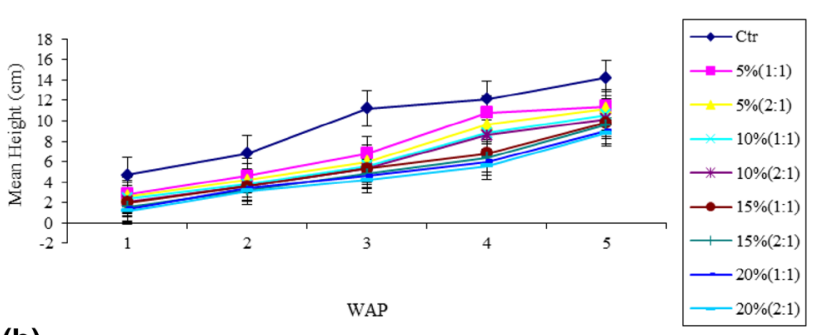

(b)

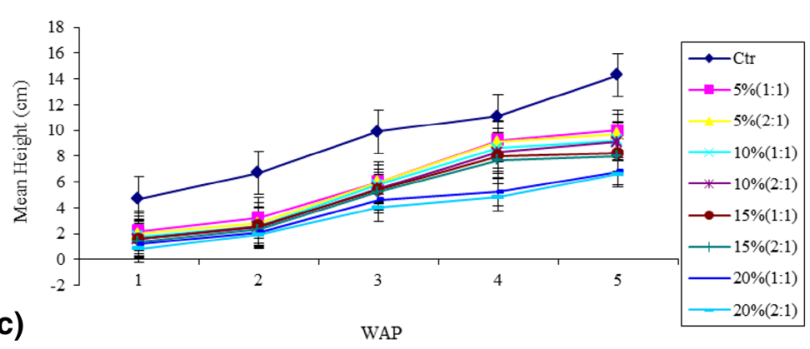

Fig. 8 Mean plant height as a function of weeks after planting (WAP) in oil-contaminated swamp forest soil amended with a cow dung, b poultry waste and $\mathbf{c}$ palm oil waste

The lowest plant height was observed at a $20 \%$ oil contamination level in soils treated with palm oil waste. The general performance of the maize plant was better in the contaminated swamp forest soil under the various treatment combinations than with fadama soil under the same treatment combinations. In the control samples of the two soils with different degrees of contamination, there were indications of poor germination and stunted growth resulting in plant death after 1 week of planting. The study showed that despite the fact that fadama soil has a higher
TPH reduction than swamp forest soil, the latter showed better plant performance. This may be attributed to the fact that swamp forest soil has good textural and physicochemical characteristics that are more suited for the growth of tropical crops like Z. mays. In terms of number of leaves, there were gross reductions in the number of leaves obtained in the plant grown in the previously contaminated and amended soils as compared with the noncontaminated soil (control). 5 weeks after planting (WAP), the mean number of leaves in the non-contaminated soil 
(control) was five for all soil types. However, the leaf number in the contaminated soils ranged from 2 to 5 . Swamp forest soil amended with poultry waste at a 1:1 amendment ratio showed a better leaf population at the different contamination levels than cow dung and palm oil waste. This is corroborated by the findings of Akujiobi et al. (2011) who reported that the remediation effect was nutrient weight dependent and the best remediation effect was observed in poultry waste-amended samples. Overall, plant performance was observed to follow the order poultry waste $>$ cow dung $>$ palm oil waste.

\section{Conclusions}

The study showed that crude oil pollution adversely affects soil fertility and physicochemical properties. Addition of organic amendments, such as cow dung, poultry waste and palm oil waste, to the contaminated soil proved to modify the physicochemical properties of the crude oilcontaminated soils and improved their nutritional status for enhanced agricultural yield of tropical crops such as Z. mays. At a 5\% contamination level, a 2:1 soil:organic amendment ratio was optimal for soil regeneration; however, at a $20 \%$ contamination level, a 1:1 soil:organic amendment ratio was optimal. For both oxisol (fadama) and utisol (swamp forest soil), oil-contaminated soils amended with PW showed a significantly $(p<0.05)$ higher rate of nitrogen mineralization than the same soil amended with either CD or POW. Fadama soils (oxisols) with a larger sand fraction showed faster TPH degradation than swamp forest soils (utisols). The order of TPH degradation in both soil types followed the order: $\mathrm{PW}>\mathrm{CD}>$ POW. Organic amendments also improved the percentage seed emergence by $48 \%$ and $49 \%$ for a $5 \%$ oil contamination level at 1:1 and 2:1 soil: organic amendment ratio, respectively. The utisols showed better plant performance, despite the fact that the oxisols showed higher rate of petroleum hydrocarbon degradation.

Open Access This article is distributed under the terms of the Creative Commons Attribution 4.0 International License (http://creativeco mmons.org/licenses/by/4.0/), which permits unrestricted use, distribution, and reproduction in any medium, provided you give appropriate credit to the original author(s) and the source, provide a link to the Creative Commons license, and indicate if changes were made.

\section{References}

Adesodun JK, Mbagwu JSC (2008) Biodegradation of waste-lubricating petroleum oil in a tropical alfisol as mediated by animal droppings. Bioresour Technol 99:5659-5665. https://doi.org/10.1016/j. biortech.2007.10.031
Akujobi CO, Onyeagba RA, Nwaugo VO, Odu NN (2011) Effect of nutrients amendments of diesel oil polluted soil on plant growth parameters. Curr Res J Biol Sci 3(4):421-429

Amadi A, Ue Bari Y (1992) Use of poultry manure for amendment of oil-polluted soils in relation to growth of maize (Zea mays L.). Environ Int 18:521-527. https://doi.org/10.1016/01604120(92)90271-5

Ayotamuno MJ, Kogbara RB, Ogaji SOT, Probert SD (2006) Bioremediation of a crude-oil polluted agricultural-soil at Port Harcourt, Nigeria. Appl Energy 83(11):1249-1257. https://doi. org/10.1016/j.apenergy.2006.01.003

Chukwu ED, Udoh BT (2014) Effect of crude oil and industrial wastes pollution on some soil chemical properties in Ikot Abasi, Niger Delta Area, Nigeria. In Proceedings of the 38th Annual Conference of the Soil Science Society of Nigeria, 10-14th March 2014, pp. $83-88$

Das N, Chandran P (2011) Microbial degradation of petroleum hydrocarbon contaminants: an overview. Biotechnol Res Int. https://doi. org/10.4061/2011/9418102011

Ekundayo JA, Aisueni N, Benka-Coker MO (1989) The effects of drilling fluid in some waste and burrow pits in western operational areas of Shell Petroleum Development Company of Nigeria Limited on the soil and water quality of the areas. Environmental Consultancy Service Group, Consultancy Services Unit, University of Benin, Benin City, pp 57-71

Ekundayo EO, Emede TO, Osayande DI (2001) Effects of crude oil spillage on growth and yield of Zea maize (Zea mays L.,) in soils of midwestern Nigeria. Foods Hum Nutr 56(4):313-324. https:// doi.org/10.1023/A:1011806706658

Etuk EA, Ogboi KC, Nwadinigwe CA (2013) Bioremediation of hydrocarbon polluted soil in the lowland forest ecosystem in the Niger Delta through enhanced natural attenuation process (ENAP). Int J Appl Sci Technol 3(8):128-137

Hérbert M, Karam A, Parent LE (1991) Mineralization of nitrogen and carbon in soils amended with composted manure. Biol Agric Hortic 7:357-364. https://doi.org/10.1080/01448765.1991.9754565

Holliger C, Gaspard S, Glod G, Heijman C, Schumacher W, Schwarzenbach RP, Vazquez F (1997) Contaminated environments in the subsurface and bioremediation: organic contaminants. FEMS Microbiol Rev 20(3-4):517-523. https://doi. org/10.1111/j.1574-6976.1997.tb00334.x

Ijah UJJ, Antai SP (2003) The potential use of chicken-drop microorganisms for oil spill remediation. Environmentalist 23(1):89-95. https://doi.org/10.1023/A:1022947727324

Iwegbue CMA (2014) Impact of land use types on the concentrations of metals in soils of urban environment in Nigeria. Environ Earth Sci 72(11):4567-4585. https://doi.org/10.1007/s12665-014-3355-x

Iwegbue CMA, Ekakitie AO, Egun AC (2006) Mineralization of nitrogen in wetland soils of the amended with hyacinth (Eichhornia $s p$ ) waste. Int J Soil Sci 1(3):258-263

Iwegbue CMA, Emuh FN, Bazunnu AO, Eguavoen O (2011) Mineralization of nitrogen in hydromorphic soils amended with organic waste. J Appl Sci Environ Manag 15(2):257-263

Iwegbue CMA, Nwajei GE, Eguavoen OI (2012) Impact of land-use patterns on chemical properties of trace elements in soils of rural, semi-urban, and urban zones of the Niger Delta, Nigeria. Soil Sed Contam 21(1):19-30. https://doi.org/10.1080/15320 383.2012.636772

Iwegbue CMA, Tesi GO, Overah LC, Emoyan OO, Nwajei GE, Martincigh BS (2017) Flooding effects on spatiotemporal characteristics of polycyclic aromatic hydrocarbons (PAHs) in floodplain soils of the lower parts of River Niger, Nigeria. Polycyclic Aromat Compd. https://doi.org/10.1080/10406638.2017.1403329

Iwegbue CMA, Tesi GO, Overah LC, Nwajei GE, Martincigh BS (2018) Chemical fractionation and mobility of metals in floodplain soils of the lower reaches of the River Niger Nigeria. 
Trans R Soc S Afr 73(1):90-109. https://doi.org/10.1080/00359 19X.2017.1361483

Iwegbue CMA, Iteku-Atata EC, Odali EW, Egobueze FE, Tesi GO, Nwajei GE, Martincigh BS (2019) Distribution, sources, and health risks of polycyclic aromatic hydrocarbons (PAHs) in household dusts from rural, semi-urban and urban areas in the Niger Delta, Nigeria. Expos Health 11(3):209-225

Madrid F, López R, Murillo JM, Cabrera F (2001) Nitrogen mineralization for assessing the correct agricultural use of MSW compost. Bioproc Solid Waste Sludge 1:6. www.orbitonline.net/journal/ archiv/01-02/0102_06_print.html

Margesin R, Schinner F (2001) Biodegradation and bioremediation of hydrocarbons in extreme environments. Appl Microbiol Biotechnol 56(5-6):650-663. https://doi.org/10.1007/s002530100701

Obasi NA, Eze E, Anyanwu DI, Okorie UC (2013) Effect of organic manures on the physicochemical properties of crude oil polluted soils. Afr J Biochem Res 7(6):67-75. https://doi.org/10.5897/ AJBR 11.113

Ogboghodo IA, Erebor EB, Osemwota IO, Isitekhale HH (2004) The effects of application of poultry manure to crude oil polluted soils on maize (Zea mays) growth and soil properties. Environ Monit Assess 96(1-3):153-161. https://doi.org/10.1023/B:EMAS.00000 31724.22352.af

Ogboghodo IA, Azenabor UF, Osemwota IO (2005) Amelioration of crude-oil-polluted soil with poultry manure and the effects on growth of maize and some soil properties. J Plant Nutr 28(1):2132. https://doi.org/10.1081/PLN-200042152

Ogbonna DN, Isirimah NO, Princewill E (2012) Effect of organic waste compost and microbial activity on the growth of maize in the utisoils in Port Harcourt, Nigeria. Afr J Biotechnol 11(62):1254612554. https://doi.org/10.5897/AJB12.494

Okolo JC, Amadi EN, Odu CTI (2005) Effects of soil treatments containing poultry manure on crude oil degradation in a sandy loam soil. Appl Ecol Environ Res 3(1):47-53
Onianwa PC, Essien CA (1999) Petroleum hydrocarbon levels in sediments of streams and rivers within Ibadan city, Nigeria. Bull Chem Soc Ethiop 13(1):83-85. https://doi.org/10.4314/bcse. v13i1.21059

Onuh MO, Madukwe DK, Ohia GU (2008) Effects of poultry manure and cow dung on the physical and chemical properties of crude oil polluted soil. Sci World J 3(2):45-50. https://doi.org/10.4314/ swj.v3i2.51785

Onuoha SC, Chukwura EI, Fatokun K (2014) Stimulated biodegradation of spent lubricating motor oil in soil amended with animal droppings. Am J Biosci 2(1):19-27. https://doi.org/10.11648 /j.ajbio.20140201.14

Osuji LC, Adesiyan SO (2005) The Isiokpo oil-pipeline leakage: total organic carbon/organic matter contents of affected soils. Chem Biodiver 2(8):1079-1085. https://doi.org/10.1002/cbdv.20059 0077

Tanee FBG, Albert E (2011) Post-remediation assessment of crude oil polluted site at Kegbara-Dere Community, Gokana L.G.A. of Rivers State, Nigeria. J Bioremed Biodegrad. https://doi. org/10.4172/2155-6199.1000122

Uquetan UI, Osang JE, Egor AO, Essoka PA, Alozie SI, Bawan AM (2017) A case study of the effects of oil pollution on soil properties and growth of tree crops in Cross River State, Nigeria. Int Res J Pure Appl Phys 5(2):19-28

Yakubu MB (2007) Biodegradation of Lagoma crude oil using pig dung. Afr J Biotechnol 6(24):2821-2825. https://doi.org/10.5897/ AJB2007.000-2450

Publisher's Note Springer Nature remains neutral with regard to jurisdictional claims in published maps and institutional affiliations. 